LONDON-The giant is stirring- Breeding Institute. Basic research again. Imperial Chemical Industries (ICI), best known by biotechnologists for its greatest failure, Pruteen singlecell protein, is showing that it firmly intends to cash in on biotechnology for both diagnostics and agriculture. And even some of its Pruteen technology is now being adapted to another protein-rich food, this time for human consumption.

It is in DNA-fingerprinting that ICI's interest in biotechnology-based diagnostics has surfaced. Early this summer, the company's new Cellmark Diagnostics subsidiary opened its first fingerprinting center in $\mathrm{Ab}$ ingdon, U.K., which is soon to be followed by a U.S. equivalent. Send the center $\$ 500$ and small samples of blood from a child and its supposed parents, and in three weeks the truth will out. Philip Webb, Cellmark's general manager, reckons that it will not be long before the present capacity of 250 tests a week is taken up, so the firm plans to increase capacity four fold.

Initial demand is coming from paternity disputes and from cases where immigration authorities are questioning alleged relationships. But there are also forensic uses of the test. Murderers and rapists can be unambiguously identified from body fluids left at the scene of the crime, as could otherwise-unrecognizable victims of war or terrorism from their remnants.

ICI has a wider interest in DNAbased diagnostics and expects also to become involved in the prenatal diagnosis of genetic diseases. It seems likely that its contribution to such tests will be in developing a service industry, rather than in fundamental discoveries. The company has an exclusive license on the DNA-fingerprint test from the Lister Institute, which pays the salary of the test's inventor, Alec Jeffries of Leicester University.

As for plant biotechnology, ICI both has committed itself to an expanded program of basic research and has been busily acquiring seed companies. Its latest purchase is the Belgium-based Société Européenne de Sémences, for which it paid $\$ 150$ million in June. It is also a declared bidder in the U.K. government's sale of its National Seed Development Organization and part of the Plant will be expanded both in Slater, Iowa, the home-base of Garst Seeds (which ICI purchased in 1985), and at Jealott's Hill, Berkshire, U.K. A capital investment of $\$ 27$ million and annual running costs of $\$ 16$ million will be invested in the general field of crop improvement by genetic manipulation.

ICI's current interest in proteinrich foods owes little to Pruteen. Quorn, as it is called, is not a new product but the result of 20 years' work on the filamentous fungus $F u$ sarium graminearum by Ranks Hovis

\section{U.K. Commancintanon}

\section{LONDON-High Wycombe is} roughly half-way between I.ondon and Oxford. So when Monsanto (St. Louis, MO) first bought up and then closed down the High Wycombe research laboratories of G.D. Searle, a group of senior staff first raised $\$ 4$ million of venture capital in London and then started British Bio-technology Limited (BBL) in Oxford. Still in its first year, the company has already cashed in on its proximity to Oxford University by exploiting a discovery that may result in new or improved vaccines. It also has its first products on the market, a range of synthetic genes, and its first contract, a deal with SmithKline Beckman (Philadelphia, $P \Lambda)$ covering thrombolytic agents.

The vaccine project is designed to overcome some of the problems of presenting antigens to the immune system in a way that provokes an adequate immune response. It is based on fundamental research on yeast molecular genetics that has been going on in Oxford's department of biochemistry under Susan and Mlan Kingsman. With patents on the work now filed, and with British Bio-technology taking a serious interest, Alan Kingsman has taken a half-time position with the company, and one of his academic colleagues has joined the firm.

Vaccine development was not at the front of BBL's mind when it set up shop. More central to its aims then, as now, was the development of

\title{
FORMER SEARLE SCIENTISTS FORM BRITISH BIO-TECHNOLOGY LTD.
}

McDougall, the L.K. foods group. The filaments are harvested, processed, textured, and flavored; the result can be a passable imitation of chicken, ham, or veal. For the past three years ICI has been involved in scaling up Quorn. Its pilot fermentor for Pruteen has been adapted to produce 20 tonnes a week for Marlow Foods (High Wycombe), a company jointly owned by ICI and Ranks Hovis McDougall. Supply has just become sufficient for Sainsbury to have launched a range of Quorn-based products throughout its chain of supermarkets.

-Peter Newmark new therapeutic agents, particularly for diseases of bone and connective tissues. With about 20 chemists and 20 molecular biologists on staff, there is research on both small active-site inhibitors of enzymes and biologically active polypeptides. Having missed the boat on the obvious first-generation polypeptides, the emphasis is on second-generation products, particularly polypeptides with fused or hybrid functional domains, selected with the aid of molecular modeling.

It is from the desire to reassort functional domains of proteins routinely that the company's first products have arisen. Its synthetic geneswhich so far are few in number and mainly for lymphokines-are constructed with convenient restriction enzyme sites between the encoded functional domains. Mark Edwards, who leads BBL's gene synthesizers, says it is too early to judge the demand for such off-the-shelf genes, but there has been demand for custom-synthesized genes. A 500-base pair gene takes about eight weeks to produce, he adds. Next in line as products are synthetic versions of biologically "mature" oligosaccharides.

With about half the scientists and all the top executives being ex-Searle, it is not surprising that much of British Bio-technology's work, including that on gene synthesis, stems from ideas generated at and patented by Searle. BBL executives have been in discussion with Monsanto in the hope of avoiding any legal problems. - PN 